\title{
An updated synopsis of Astraea Klotzsch (Crotoneae, Euphorbiaceae) for the State of São Paulo, Brazil
}

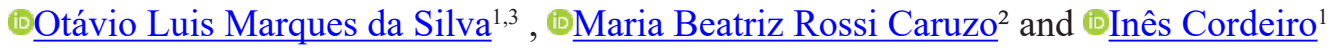

Received: 21 May 2019; accepted: 9 August 2019

How to cite: Silva, O.L.M., Caruzo, M.B.R. \& Cordeiro, I. 2019. An updated synopsis of Astraea Klotzsch (Crotoneae, Euphorbiaceae) for the State of São Paulo, Brazil. Hoehnea 46: e582019. http://dx.doi.org/10.1590/2236-8906-58/2019.

ABSTRACT - (An updated synopsis of Astraea Klotzsch (Crotoneae, Euphorbiaceae) for the State of São Paulo, Brazil.) Euphorbiaceae is one of the richest families in the State of São Paulo, with 37 genera and around 150 species. A synopsis of Astraea was published as part of the treatment for the tribe Crotoneae, but recent taxonomic and systematic advances have brought a more refined knowledge about the genus, especially for the widespread Astraea lobata. This species had its morphological delimitation poorly defined until very recently and, as a result, about five species were distinguished based on morphological characters. In this work, we update the synopsis of Astraea as part of the taxonomic revision of the genus and studies on Euphorbiaceae for the Flora Fanerogâmica do Estado de São Paulo project. We present an identification key, photographs of diagnostic characters, and an updated distribution map for the five species of Astraea found in São Paulo, along with a list of specimens for the state.

Keywords: Flora Fanerogâmica do Estado de São Paulo, taxonomy

RESUMO - (Sinopse atualizada de Astraea Klotzsch (Crotoneae, Euphorbiaceae) para o Estado de São Paulo, Brasil.) Euphorbiaceae é uma das famílias mais ricas em espécies no Estado de São Paulo, com 37 gêneros e cerca de 150 espécies. A sinopse de Astraea foi publicada como parte do tratamento para a tribo Crotoneae, mas avanços taxonômicos e sistemáticos recentes trouxeram um conhecimento mais refinado sobre o gênero, especialmente para a amplamente distribuída Astraea lobata. Esta espécie tinha sua delimitação morfológica mal definida até muito recentemente e, como resultado, cerca de cinco espécies foram reconhecidas com base em caracteres morfológicos. Neste trabalho, nós atualizamos a sinopse de Astraea como parte da revisão taxonômica do gênero e estudos em Euphorbiaceae para o projeto Flora Fanerogâmica do Estado de São Paulo. Nós apresentamos uma chave de identificação, fotografias de caracteres diagnósticos, e um mapa de distribuição atualizado com as cinco espécies de Astraea encontradas em São Paulo, junto com uma lista de exsicatas para o Estado.

Palavras-chave: Flora Fanerogâmica do Estado de São Paulo, taxonomia

\section{Introduction}

Astraea Klotzsch is a small genus in Euphorbiaceae with 13 species, widely distributed throughout the Neotropics, but especially diverse in eastern Brazil. It is also found in the Paleotropics, where it is represented by weedy species (Caruzo et al. 2014, Silva \& Cordeiro 2017, Silva et al. 2017, Silva et al. 2019). The genus was traditionally recognized as a section of the giant Croton L., due to its spiciform inflorescences and stamens inflexed in bud, and was considered one of the best morphologically defined groups within Croton by its usually deeply lobed/partite leaves, glabrous receptacle of staminate flowers and seeds cylindric-tetragonous (Webster 1993). Recent phylogenetic studies (Berry et al. 2005a, Wurdack et al. 2005) recognized Astraea again as a distinct genus, once it was separated from the remaining Croton with the positioning of Brasiliocroton P.E. Berry \& Cordeiro, a recent described genus with two species (Berry et al. 2005b, Riina et al. 2014), as most closely related to Croton. These studies also showed that Astraea is sister to Acidocroton Griseb. (including Ophellantha Standl. According to Webster [2014]), a genus found in Greater Antilles, Central America and northern South America (Webster 2014).

Recent advances in the taxonomy of Astraea (Silva \& Cordeiro 2017, Silva et al. 2019), have

1. Instituto de Botânica, Núcleo de Pesquisa Curadoria do Herbário SP, Avenida Miguel Estefno, 3687, São Paulo, 04045-972 SP, Brasil

2. Universidade Federal de São Paulo, Departamento de Ecologia e Biologia Evolutiva, Rua Professor Artur Riedel, 275, Diadema, 09972-270 SP, Brasil

3. Corresponding author: otaviolmarques@gmail.com 
shown that Astraea lobata s.l., the most widespread species within the genus, hid under its poorly defined morphological delimitation other species, such as Astraea digitata (Müll.Arg.) O.L.M. Silva \& Cordeiro, Astraea manihot (Müll.Arg.) O.L.M. Silva $\&$ Cordeiro and Astraea surinamensis (Miq.) O.L.M. Silva \& Cordeiro. The distinction of such species from Astraea lobata s.s. is supported by morphology (Silva et al. 2017, 2019), as well as by a phylogenetic framework built for the genus by Silva et al. (in prep.).

In this work, our aim is to present an update for the synopsis of Astraea in the State of São Paulo, published by Caruzo \& Cordeiro (2007), accounting for the recent taxonomic changes mentioned above, with illustrations and photographs of diagnostic characters and an updated distribution map of Astraea in the State of São Paulo.

\section{Materials and methods}

Herbarium specimens analyzed for the purpose of this work include the full database for the taxonomic revision of Astraea, containing ca. 5200 specimens from more than 90 herbaria - A, ALCB, AMD, ASE, B, BHCB, BHZB, BM, BOTU, BR, C, CEN, CEPEC, CESJ, CGMS, COL, CTES, CVRD, DAV, E, EAC, ESA, F, FHI, FLAS, FSU, FTG, FUEL, G, GH, HAL, HB, HBG, HCF, HEPH, HNBU, HRB, HRCB, HUEFS, HUEM, HUFU, IAC, IBGE, IEB, INPA, IPA, JPB, K, L, LE, LINN, M, MA, MAC, MBM, MBML, MG, MEXU, MICH, MO, MPU, NY, OUPR, P, PACA, PAMG, PEUFR, R, RB, RSA, S, SJRP, SP, SPF, SPSF, TCD, TOGO, TUB, U, UB, UC, UEC, UESC, UFG, UFP, UFRN, US, USF, USZ, VIC, VIES, W, WAG and WIS (abbreviations according to Thiers 2019, continuously updated). For the State of São Paulo, 74 specimens were analyzed, along with collecting trips for observation of populations in the field.
The conservation status for each species was accessed following the criteria established by Mamede et al. (2007). The distribution map was elaborated with QGIS v.3.4 (Quantum GIS Development Team 2019). Specimens were georeferenced using original coordinates obtained from herbarium labels (converted to decimal degrees when necessary through conversor [available at splink.cria.org.br/conversor]). When original coordinates were not available we used approximate coordinates from municipalities or localities obtained from geoLoc (available at splink.cria.org.br/geoloc).

\section{Results and Discussion}

In the State of São Paulo, Astraea is represented by five species: A. gracilis (Müll.Arg.) O.L.M. Silva \& Cordeiro, A. lobata, A. manihot, A. paulina Didr.., and A. surinamensis. This represents an addition of four species to the Checklist of Spermatophyta in São Paulo (Wanderley et al. 2011), which, for Astraea, was based on the synopsis of Caruzo \& Cordeiro (2007). Most of these novelties are recent combinations by Silva \& Cordeiro (2017) and Silva et al. (2019) based on previously recognized varieties by Müller Argoviensis $(1866,1873)$, except for Astraea paulina, which was considered as synonym of Astraea lobata by Caruzo \& Cordeiro (2007) and is currently recognized as a distinct species (Silva et al. 2019). Astraea cincta (Müll.Arg.) Caruzo \& Cordeiro is not included in this updated synopsis, since the only register for the State of São Paulo was its type collection, indicated as São Paulo by Müller Argoviensis (1873), but corrected to Mato Grosso do Sul by Silva et al. (2019).

Astraea is found in all regions and main vegetations types present in the State of São Paulo, except for mangroves, where none Euphorbiaceae is found (figure 1; Caruzo \& Cordeiro 2007).

Identification key to the species of Astraea in the State of São Paulo

1. Young branches and petioles hirsute, with stellate-porrect trichomes bearing a central ray much longer than the lateral rays, exceeding $1.5 \mathrm{~mm}$ in length (giving an appearance of an indumentum composed by simple long trichomes) 5. A. surinamensis

1. Young branches and petioles glabrous, pilose or pubescent, with short $(<0.5 \mathrm{~mm})$ simple, stellate or stellate-porrect trichomes bearing a central ray equal or slightly longer than the lateral rays, not exceeding $1 \mathrm{~mm}$ in length

2. Fruits opaque. Plants from disturbed sites 2. A. lobata

2. Fruits lustrous. Plants from the edge of wet or seasonally dry forests or gallery forests

3. Pistillate flowers long-pedicellate (pedicel with 3-5 mm long). Staminate cymules with 6-8(-10) flowers 3. A. manihot

3. Pistillate flowers sessile to short-pedicellate (pedicel not exceeding $2.5 \mathrm{~mm}$ long). Staminate cymules with up to 5(-6) flowers

4. Leaves chartaceous, adaxial surface with short $(<0.5 \mathrm{~mm})$ simple or stellate trichomes 4. A. paulina 4. Leaves membranaceous, adaxial surface with long $(>0.5 \mathrm{~mm})$ simple trichomes 1. A. gracilis 


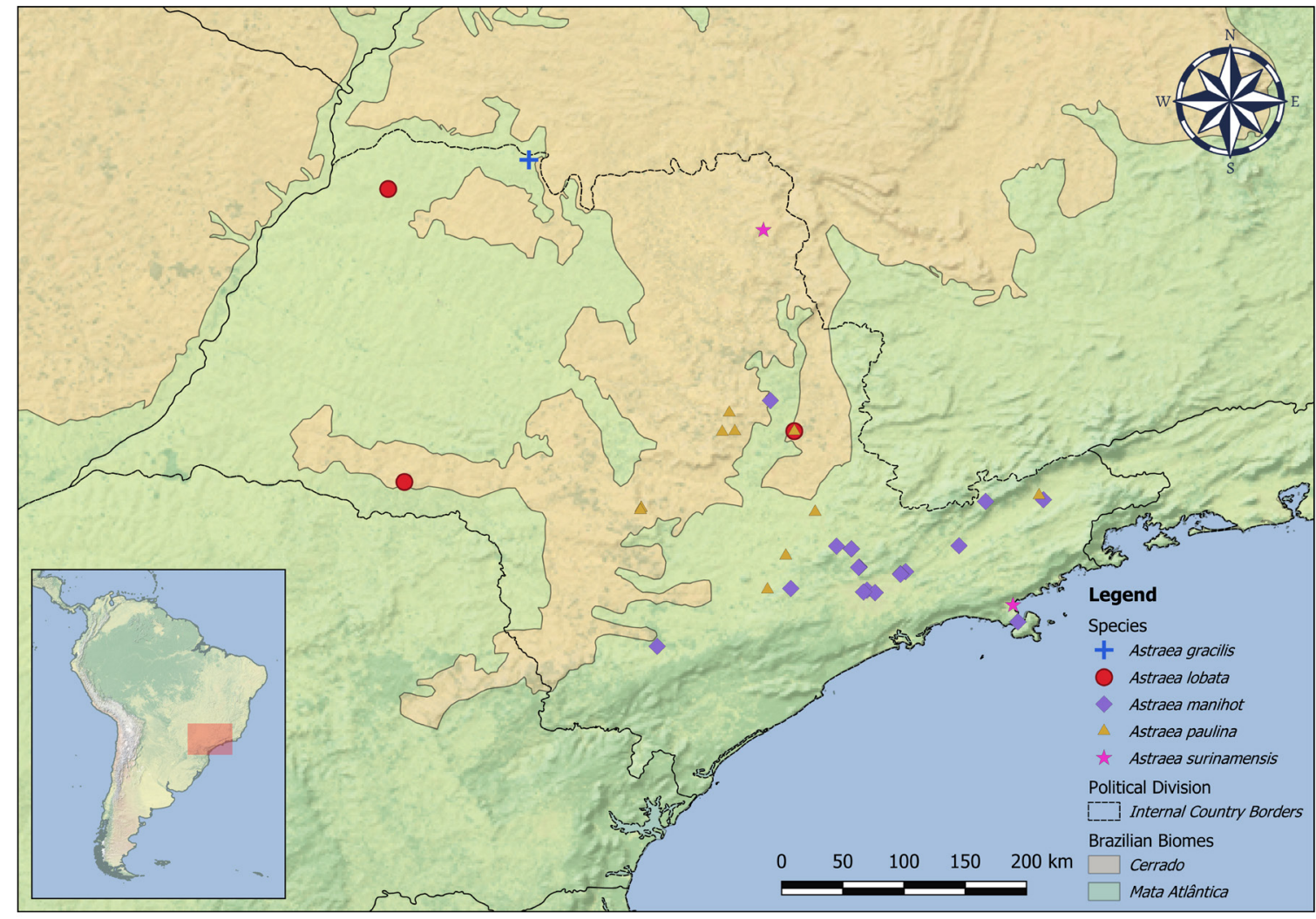

Figure 1. Distribution map of the species of Astraea in the State of São Paulo, Brazil.

1. Astraea gracilis (Müll.Arg.) O.L.M. Silva \& Cordeiro, Phytotaxa 317(4): 299. 2017. TYPE: BRAZIL. RIODE JANEIRO: 'in pascuis montanis prope Sebastianopolis',Martiuss.n. (lectotype G00312451!, isolectotypes M0089080!, M0089081!, M0089082!).

Figure 2a-c

Selected material: BRAZIL. SÃo PAulo: Paulo de Faria, Estação Ecológica de Paulo de Faria, 17-I-2002, F. Tomasetto et al. 212 (HRCB, HSJRP, SP).

In the State of São Paulo, Astraea gracilis is only found in the northwestern portion of the state, near the boundary with the state of Minas Gerais (figure 1). However, Astraea gracilis is a species widely distributed in South America, found throughout the South American dry diagonal, with a few collections also in French Guiana, occurring mostly in edges of wet and seasonally dry forests or rocky outcrops (Silva \& Cordeiro 2017). Morphological features that can be used to distinguish Astraea gracilis from Astraea lobata include the lustrous fruit (figure 2c; vs. opaque in Astraea lobata), adaxial surface of leaves with long $(>0.5 \mathrm{~mm}$ ) simple trichomes (figure $2 \mathrm{a}$; vs. short $[<0.5 \mathrm{~mm}]$ simple or stellate trichomes in
Astraea lobata) and geographical distribution and habitat, since Astraea lobata is found on disturbed sites along western and northwestern South America, Central America, Antilles, Mexico and Florida.

Astraea gracilis, although widely distributed in South America, has a restricted distribution in the State of São Paulo, with all specimens collected in the municipality of Paulo de Faria, within a protected area (Paulo de Faria Ecological Station) and in the same vegetation type. Therefore, Astraea gracilis is considered here as "Endangered" once it qualifies for criteria 3, 5 and 9 of Mamede et al. (2007).

2. Astraea lobata (L.) Klotzsch, Arch. Naturgesch. 7(1): 194. 1841. TYPE: MÉXICO. VERACRUZ: Herb. Clifford 445 (lectotype BM000647404!).

Figure 2d-e

Selected material: BRAZIL. SÃo Paulo: Assis, Estação Experimental, região da serraria velha, 15-V-1995, V.S. Moura 24 (SPSF).

Additional examined material: BRAZIL. MATo Grosso do Sul: Três Lagoas, Rodovia CESP, próximo ao início da ponte sobre o Rio Paraná (BR-262), 31-I-2014, O.L.M. Silva \& R.F. Almeida 121 (SP). 


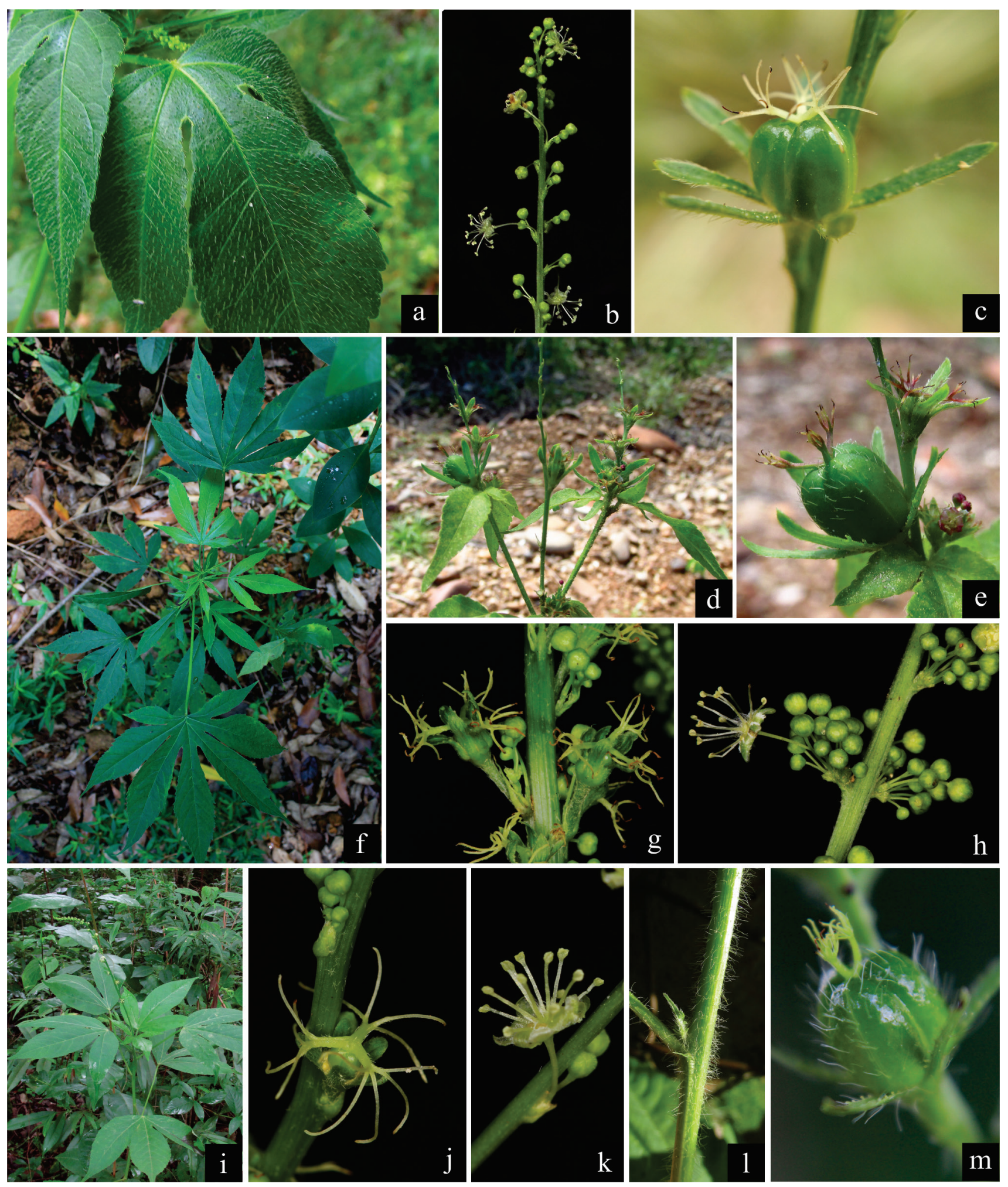

Figure 2. Diagnostic characters of the species of Astraea in State of São Paulo, Brazil State. a-c. Astraea gracilis: a. adaxial surface of leaf. b. staminate cymules. c. immature lustrous fruit. d-e. Astraea lobata: d. inflorescences. e. pistillate flower and opaque immature fruit. f-h. Astraea manihot: f. young individual with 3-, 5- and 7-partite leaves. g. pistillate flowers in basal bisexual cymules. h. staminate cymules with one mature flower. i-k. Astraea paulina: i. young individual. j. pistillate flower. k. staminate cymules with one mature flower. 1-m. Astraea surinamensis: 1. young portion of a branch showing hirsute indument. m. immature lustrous fruit. Photos: O.L.M. Silva. Vouchers. a: O.L.M. Silva 223; b, c: O.L.M. Silva 224; d, e: O.L.M. Silva 120; f: O.L.M. Silva 237; g, h: O.L.M. Silva 323; i: O.L.M. Silva 112; j, k: O.L.M. Silva 335; 1: O.L.M. Silva 117; m: O.L.M. Silva 247. 
Astraea lobata is one of the most widely distributed species of the genus, occurring in western and northwestern South America, Central America, Antilles, Mexico, and Florida. However, in the State of São Paulo it is represented by a few collections (figure 1). Under the morphological delimitation presented by Silva et al. (2019), this species is mainly characterized by its opaque fruits (figure 2e), shared only with Astraea cincta, and pistillate flowers usually with strongly accrescent calyx lobes, which surpass the mature fruit, reaching up to $1(-2) \mathrm{cm}$ long. (figure 2d). Among the species found in São Paulo, these strongly accrescent calyx lobes in pistillate flowers are also present only in Astraea gracilis (figure 2c), from which A. lobata may be distinguished by the irregularly serrate margin of such lobes (vs. entire in Astraea gracilis), beyond habitat preferences (see comments under Astraea gracilis).

Astraea lobata is here considered as "Least Concern" following the exclusion criterion of Mamede et al. (2007), in which ruderal or invasive species are included.

3. Astraea manihot (Müll.Arg.) O.L.M. Silva \& Cordeiro, Phytotaxa 317(4): 299. 2017. TYPE: BRAZIL. MinAs GERAIS: Caldas, 1846, Widgren 364 (lectotype S17-36789!, isolectotypes BR00583842!, BR00583843!, BR00583844!, S17-36787!).

Figure 2f-h

Selected material: BRAZIL. SÃo PAulo: Santo Antonio do Pinhal, Início do Roteiro Turístico das Flores, na subida, cerca de $100 \mathrm{~m}$ antes do início do trecho em estrada de terra, 11-I-2017, O.L.M. Silva et al. 328 (SP).

Astraea manihot is found in southern Brazil in the states of Minas Gerais, Espírito Santo, Rio de Janeiro, and Paraná, besides São Paulo, where it is found mostly in the southeastern portion of the State (figure 1). This species grows in edges of humid forests and in gallery forests in Cerrado. The shrubby habit, predominantly 5-partite leaves with narrow lobes (figure 2f), long-pedicellate pistillate flowers (figure $2 \mathrm{~g}$ ) and staminate cymules with more than 6 flowers (figure $2 \mathrm{~h}$ ) distinguish this species from Astraea lobata, which has herbaceous habit, 3(-5)-partite leaves with elliptic lobes, subsessile pistillate flowers (figure 2e) and staminate cymules with up to 3 flowers. The number of flowers in each staminate cymule is also useful to distinguish Astraea manihot from the remaining species of Astraea in the State of São
Paulo: Astraea gracilis has 3-4 flowers in each cymule (figure 2b); Astraea paulina 2-5 (figure 2k); and $A$. surinamensis 1-3.

Astraea manihot does not qualify for any of the inclusive or exclusive criteria of Mamede et al. (2007) and, therefore, is here considered as "Least Concern".

4. Astraea paulina Didr., Vidensk. Meddel. Dansk. Naturhist. Foren. Kjobenhavn part 9-10: 138. 1857. TYPE: BRAZIL. SÃo PAULO: Itu, II-1834, Lund s.n (holotype C, isotype G00312455!).

Figure 2i-k

Selected material: BRAZIL. SÃo PAUlo: Botucatu, Caminho para Igreja Santo Antonio no distrito Rubião Júnior. Curva antes da subida final, logo após o portão, margem esquerda, 30-I-2015, O.L.M. Silva et al. 213 (SP).

Astraea paulina was included as a synonym of Astraea lobata in Caruzo \& Cordeiro (2007), but they may be distinguished mainly by habit (shrubby in Astraea paulina [figure 2i] vs herbaceous in Astraea lobata) and fruits (lustrous in Astraea paulina and matte in Astraea lobata). Also, while Astraea paulina is widely distributed along the diagonal of dry areas of South America, occurring in habitats such as rocky grasslands (campos rupestres), seasonally dry forests or gallery forests along the Cerrado domain, A. lobata is found from Mexico to southern Brazil, but it is more common in western South America, occurring mainly in disturbed areas.

Astraea paulina does not qualify for any of the inclusive or exclusive criteria of Mamede et al. (2007) and, therefore, is considered as "Least Concern".

5. Astraea surinamensis (Miq.) O.L.M. Silva \& Cordeiro, Phytotaxa 404(4): 133. 2019. TYPE: SURINAME. Paramaribo: 'in agris pr. urb. Paramaribo', 1844, Kappler 1573 (lectotype U0001887 [photo!], isolectotypes G!, P04831490!, TUB009125 [photo!], TUB009125 [photo!]).

Figure 21-m

Selected material: BRAZIL. São PAUlo: Caraguatatuba, Bairro dos Golfinhos, 21-I-2018, U.G. Fernandes \& A.P. Della 483 (SP).

Astraea surinamensis is another widespread species in Astraea found throughout Brazil. However, while Astraea lobata is mainly found in western South America, Central America, Greater Antilles and North America (Mexico and Florida), Astraea surinamensis is mainly distributed in eastern and northern South America and the Lesser Antilles, 
with very few specimens in Central America and Africa. In the State of São Paulo, this species is represented by a few collections (figure 1), most likely due to a lack of collections rather than to a narrow distribution.

These two species may be distinguished by the characteristic stellate-porrect trichomes bearing a central ray much longer than the lateral ones (surpassing $1.5 \mathrm{~mm}$ in length) found on young portion of branches and petioles (figure 21) in Astraea surinamensis, while, although stellate-porrect trichomes may also be found in Astraea lobata, they do not surpass the lateral rays by more than $1.5 \mathrm{~mm}$. Also, fruits of Astraea surinamensis are lustrous and possess long ( $>1 \mathrm{~mm}$ ) simple trichomes (figure $2 \mathrm{~m}$ ), while in Astraea lobata fruits are matte and have stellate or short $(<0.5 \mathrm{~mm})$ simple trichomes.

Astraea surinamensis is here considered as "Least Concern" following the exclusion criterion of Mamede et al. (2007), in which ruderal or invasive species are included.

\section{List of specimens}

Almeida-Scabbia, R.J. 713 (manihot); AmaralJúnior, A. 2052 (paulina), 2075 (paulina); Barreto, K.D. 1462 (paulina); Barros, A.A.M. 518 (manihot); Bicudo, L.R.H. 1 (paulina); Brade, A.C. 7336 (manihot), 7337 (manihot); Braga, L.M. 1 (paulina); Caruzo, M.B.R. 55 (paulina), 77 (paulina); De-Paula, O.C. 10 (paulina); Dinato, D.O. 271 (paulina), Fernandes, U.G. 483 (surinamensis); Ferreira, V.F. 3303 (paulina); Fina, B.G. 57 (manihot); Gemtchújnicov, I.D. BOTU 9826 (paulina); Giannotti, E. 8379 (paulina); Hoehne, F.C. s.n. SP 1521 (manihot); Hoehne, W. R 149074 (lobata), R 149075 (manihot); Jung, S.L. 32 (manihot), 33 (manihot), 34 (manihot), 35 (manihot), 36 (manihot); Kuhlmann, M. 3700 (lobata); Lamand, A. 20 (paulina); Loefgren, A. 263 (manihot); Luederwaldt, H. SP 13819 (manihot); Makino, H. MG 129114, SP 146648, UEC 4658, UEC 111065 (manihot); Martius, C.F.P. von M 233649 (manihot); Mattos, J.R. 8512 (paulina); 13935 (manihot); Mosén, H. 1628 (paulina); Moura, V.S. 24 (lobata); Rabelo, J.C. 42 (paulina); Rossi, L. 1073 (manihot), 2396 (manihot); Russel, A. 129 (paulina); Silva, O.L.M. 139 (manihot), 213 (paulina), 233 (manihot), 234 (manihot), 235 (manihot), 236 (manihot), 328 (manihot); Souza, V.C. 35738 (surinamensis);
Stranghetti, V. 460 (gracilis); Tomasetto, F. 212 (gracilis); Tozzi, A.M.G.A. 313 (manihot).

\section{Acknowledgements}

We thank the curators of all the herbaria cited in this work for providing access to their collections. We are grateful to FAPESP for the scholarships awarded to O.L.M. Silva (FAPESP process numbers 2013/26501-6 and 2017/06171-2) and to CNPq for the financial support to I. Cordeiro (CNPq process number 309917/2015-8).

\section{Literature cited}

Berry, P.E., A.L. Hipp, K.J. Wurdack, B. van Ee \& R. Riina. 2005a. Molecular phylogenetics of the giant genus Croton and tribe Crotoneae (Euphorbiaceae sensu stricto) using ITS and trnL-trnF DNA sequence data. American Journal of Botany 92: 1520-1534.

Berry, P.E., Cordeiro, I., Wiedenhoeft, A.C., VitorinoCruz, M.A. \& Lima, L.R. 2005b. Brasiliocroton, a new crotonoid genus of Euphorbiaceae s.s. from Eastern Brazil. Systematic Botany 30: 357-365.

Caruzo, M.B.R. \& Cordeiro, I. 2007. Sinopse da tribo Crotoneae Dumort. (Euphorbiaceae s.s.) no Estado de São Paulo, Brasil. Hoehnea 34: 571-585.

Caruzo, M.B.R., O.L.M. Silva, P.E. Berry \& I. Cordeiro. 2014. Nomenclatural novelties in Astraea (Euphorbiaceae). Phytotaxa 159: 127-128.

Mamede, M.C., Souza, V.C., Prado, J., Barros, F., Wanderley, M.G.L. \& Rando, J.G. 2007. Livro Vermelho das Espécies Vegetais Ameaçadas do Estado de São Paulo. Instituto de Botânica de São Paulo, São Paulo.

Müller Argoviensis, J. 1866. Euphorbiaceae. In: A.L.P.P. Candolle (eds.). Prodromus Systematics Universalis Regni Vegetabilis, Victor Masson, Paris.

Müller Argoviensis, J. 1873. Euphorbiaceae. In: C.F.P. von Martius \& A.W. Eichler (eds.). Flora Brasiliensis. v 11, Frid. Fleischer, München.

Quantum GIS Development Team. 2019. Quantum GIS Geographic Information System. Open Source Geospatial Foundation Project. Available in https:// www.qgis.org/en/site/forusers/download.html (access in 17-V-2019).

Riina, R., D.S. Carneiro-Torres, J.A. Peirson, P.E. Berry \& I. Cordeiro. 2014. Further support for the Crotoneae Phylogeny: A New Species of Brasiliocroton (Euphorbiaceae) Based on Morphological, Geographical, and Molecular Evidence. Systematic Botany 39: 227-234. 
Silva, O.L.M. \& Cordeiro, I. 2017. Disentangling Astraea lobata: three new names in Astraea based on previous varieties of Croton lobatus (Euphorbiaceae). Phytotaxa 317: 297-300.

Silva, O.L.M., Banzato, T.C., Bedendo, I.P. \& Cordeiro, I. 2017. A report of infestation by phytoplasma in Astraea (Euphorbiaceae) and its taxonomic implications in Astraea douradensis. Phytotaxa 332: 195-198.

Silva, O.L.M., Dias, P., Riina, R. \& Cordeiro, I. 2019. Redelimitation of Astraea lobata (Euphorbiaceae) and other taxonomic rearrangements in Astraea. Phytotaxa 404: 127-136.

Thiers, B. 2019. Index Herbariorum: A global directory of public herbaria and associated staff. The New York Botanical Garden, New York. Available in http:// sweetgum.nybg.org/ih/ (access 17-V-2019).
Wanderley, M.G.L., Shepherd, G.J., Martins, S.E., Estrada, T.E.M.D., Romanini, R.P., Koch, I., Pirani, J.R., Melhem, T.S., Harley, A.M.G., Kinoshita, L.S., Magenta, M.A.G., Wagner, H.M.L., Barros, F., Lohmann, L.G., Amaral, M.C.E., Cordeiro, I., Aragaki, S., Bianchini, R.S. \& Esteves, G.L. 2011. Checklist of Spermatophyta of the São Paulo State, Brazil. Biota Neotropica 11: 193-390.

Webster, G.L. 1993. A provisional synopsis of the sections of the genus Croton (Euphorbiaceae). Taxon 42: 793-823.

Webster, G.L. 2014. Euphorbiaceae. In: K. Kubitzki (ed.). The families and genera of vascular plants 11, SpringerVerlag, Berlin, pp. 51-216.

Wurdack, K.J., P. Hoffman \& M.W. Chase. 2005. Molecular phylogenetic analysis of uniovulate Euphorbiaceae (Euphorbiaceae sensu stricto) using plastid rbcL and trnL-F DNA sequences. American Journal of Botany 92: 1397-1420. 